\title{
PSA Level Less than or Equal to Four
}

National Cancer Institute

\section{Source}

National Cancer Institute. PSA Level Less than or Equal to Four. NCI Thesaurus. Code C156007.

A blood concentration of prostate specific antigen less than or equal to $4 \mathrm{ng} / \mathrm{mL}$. 